\title{
MENSAGENS CIFRADAS: PARANOIA EM 2666 DE ROBERTO BOLAÑO
}

\section{ENCRYPTED MESSAGES: PARANOIA IN ROBERTO BOLAÑO'S 2666}

\section{Antônio Carlos Silveira Xerxenesky ${ }^{193}$}

RESUMO: Este artigo discute a maneira como a imaginação paranoide uma marca recorrente da literatura contemporânea, na opinião de críticos como Stefano Ercolino - se manifesta nas duas primeiras seções do romance 2666, do autor chileno Roberto Bolaño. Traçando breves paralelos com a produção de Philip K. Dick e Thomas Pynchon, discutese o que os romances e contos de Bolaño oferecem de singular, e de que modo sua obra simboliza um caminho para a produção literária que gira em torno de conceitos como fragmentação e a arte do excesso.

Palavras-chave: Literatura latino-americana; paranoia; literatura comparada; fragmentação; excesso.

ABSTRACT: This article discusses the way in which a paranoid imagination - something quite recurrent in contemporary literature, according to critics such as Stefano Ercolino - appears in the first two parts of the novel 2666, by Chilean author Roberto Bolaño. Sketching brief parallels between Philip K. Dick's and Thomas Pynchon's oeuvres with Bolaño's novels and stories, the article discusses what Bolaño's work offers which is unique to the author and how it shows a path for a literary writing style that orbits around concepts such as fragmentation and the art of excess.

Keywords: Latin American literature; paranoia; comparative literature; fragmentation; excesso.

${ }^{193}$ Doutor em Teoria Literária e Literatura Comparada pela Universidade de São Paulo-USP. 


\section{A paranoia dos críticos}

Este artigo é focado nas duas primeiras seções do romance póstumo do autor chileno Roberto Bolaño, 2666 (2004a), e busca analisar a maneira como a paranoia é articulada pelos seus personagens, e como esta mesma paranoia é sintomática de um modo de escrita que perpassa toda a obra em questão. Para fins comparativos, traçam-se paralelos entre a produção literária de Bolaño e a de outros autores norteamericanos que integravam as leituras do chileno e que muitas vezes são citados por ele.

A questão da paranoia é recorrente em discussões críticas que propõem um recorte panorâmico da produção ficcional atual. 2666 foi recentemente incluído como exemplo de literatura maximalista contemporânea no aclamado estudo The Maximalist Novel: From Thomas Pynchon's Gravity's Rainbow to Roberto Bolaño's 2666, de Stefano Ercolino (2014). Nessa obra, Ercolino toma como corpus ficcional os seguintes livros: O arco-íris da gravidade, de Thomas Pynchon, Graça infinita, de David Foster Wallace, Submundo, de Don DeLillo, As correções, de Jonathan Franzen, 2005 dopo Cristo, de Babette Factory, e, por fim, 2666.

Ainda na introdução, o teórico lista os dez elementos que definem o gênero do romance maximalista: dimensão (o quão extenso é o livro), modo enciclopédico, coro dissonante, exuberância diegética, completude, onisciência narrativa, imaginação paranoica, intersemioticidade, comprometimento ético e realismo híbrido. De acordo com Ercolino, essas características não têm a mesma importância nos romances que ele decide analisar, mas todas estariam "copresentes" (ERCOLINO, 2014a, p. xii). A imaginação paranoica, então, é o tópico específico que abordarei nesse artigo - como a literatura de Bolaño se relaciona com a paranoia e no que difere de exemplos canônicos da produção norte-americana, maximalista ou não?

Para Ercolino, na imaginação paranoide das personagens, exposta nos romances citados, tudo está conectado através de uma ordem secreta; o pesquisador menciona que só ao final de 2666 conseguimos organizar a trama, relacionando-a ao início, fechando o círculo (ERCOLINO, 2014a, pp. 111-12). Discordo desta visão totalizante acerca de 2666, mas, para a finalidade deste artigo, serão abordadas apenas as duas primeiras partes do romance. Interessa, portanto, analisar como se manifesta nas tramas e personagens a imaginação paranoica e o que esta apresenta de relevante para pensar a produção literária do século XXI. 
Os protagonistas de Bolaño tendem a ser criaturas confusas que contam suas histórias em testemunhos delirantes em primeira pessoa (Amuleto, diversos narradores de Los detectives salvajes, Nocturno de Chile, "El ojo Silva"). O leitor, então, tem acesso a um narrador não confiável, que esquece detalhes e o preenche com incertezas. 2666, apesar de ter um narrador em terceira pessoa, muitas vezes adentra a consciência e a inconsciência dos personagens e se deixa contaminar.

Um exemplo muito esclarecedor de como as incertezas se articulam na prosa de Bolaño está no conto "Gómez Palacio", de Putas assassinas (2008b), que é repleto de frases que desviam de uma descrição definitiva. Quando imagina o passado de um aluno de sua oficina literária, o narrador o vê "como tinha sido aos quinze anos ou talvez aos doze” (BOLAÑO, 2008, p. 30). Por que uma descrição imprecisa quando se trata de um narrador imaginando uma cena? Se é uma imaginação, por que ele não define a idade - ou quinze, ou doze? Mais adiante no conto há uma demonstração clara do tipo de estratégia narrativa de Bolaño para registrar essa indecisão:

Estiquei as pernas, um carro passou junto de mim buzinando. Xinguei-lhe a mãe com um gesto. Talvez não tenha sido apenas um gesto. Talvez tenha gritado vá pra puta que pariu e o chofer me viu ou ouviu. Mas isso, como quase tudo nesta história, é improvável. (BOLAÑO, 2008b, p. 32)

Chegamos então a 2666 que, por sua vez, é um romance que começa empregando um estilo narrativo totalmente de acordo com os padrões realistas. Porém, os personagens (até os mais distantes) são atraídos, como que pela força da gravidade, a um buraco negro que tudo suga, à violência incompreensível dos crimes ${ }^{194}$. A estratégia de Bolaño para lidar com essa conspiração é a de circulá-la (através de personagens que acabam se envolvendo indiretamente com a história), adentrá-la

194 A referência ao buraco negro também é feita por Rubén Medina, ligando 2666 ao manifesto infrarrealista, que começa com metáforas astrofísicas. Para Medina, "What is 2666 if not a big black hole of humanity, crime and horror? How can this evil be understood?". (MARISTAIN, 2014, p. 80) 
438 | Antônio Carlos Silveira Xerxenesky

(através da narração relatorial dos pormenores de cada crime), mas nunca a resolver.

Trata-se, portanto, de um movimento - ou de um arco macroestrutural - que vai da busca pela certeza à incerteza. Porém, a incerteza angustia seus personagens, que tentam encontrar uma lógica a partir dos símbolos que registram e se somam, sem encadeamento óbvio. Quem conecta os símbolos são os personagens - se estão corretos nas suas interpretações, cabe ao leitor decidir.

Em VALIS (1981), obra de ficção científica da fase tardia do americano Philip K. Dick ${ }^{195}$, na qual o próprio escritor é protagonista, mas está cindido entre ele, Philip, e seu alter ego, Horselover Fat. Fat pensa ter descoberto uma realidade subjacente à que nós experimentamos - ou seja, pensa que nosso mundo é uma ilusão. Em tudo ao seu redor, enxerga símbolos e códigos que parecem sinalizar que a sua visão é verdadeira. Fat assiste a um filme chamado VALIS, uma ficção científica sobre uma sonda extraterrestre, e acredita ver ali uma comprovação de suas teorias. Philip, por outro lado, representa o lado cético, que puxa Fat de volta para a realidade, que questiona seus delírios metafísicos. De um lado, a normalidade; do outro, a paranoia. $\mathrm{O}$ protagonista percorre o romance inteiro cindido e não encontra nenhuma resolução tranquilizadora no horizonte.

Roberto Bolaño constrói uma ponte entre sua escrita realista e a ficção de Dick em uma entrevista que cedeu a Carmen Boullosa: "Acerca de mi obra, no sé qué decirte. Supongo que es realista. A mí ya me gustaría ser un escritor fantástico, como Philip K. Dick, aunque a medida que pasan los años y me hago más viejo Dick me parece, también, cada vez más realista”. (BOULLOSA, 2006, pp. 106-07)

195 Embora nunca tenha escrito uma ficção científica, Bolaño foi profundamente influenciado por Philip K. Dick, como relata em artigos reunidos em Entre paréntesis (2004b), e como está mais do que claro no romance de publicação póstuma El espiritu de la ciencia ficción (2016), escrito originalmente em 1984 e descoberto apenas recentemente. Los sinsabores del verdadero policía (2011) é, inclusive, dedicado ao autor. Porém, Bolaño nunca trabalhou com tramas espetaculosas e exageradas na sua prosa como Dick. O mistério central, ou a grande conspiração, de um livro como 2666 (BOLAÑO, 2004a) não envolve alienígenas, e tem como pano de fundo crimes reais que são narrados em detalhes excruciantes, como num relatório forense. 
Onde estaria o realismo de Dick? Talvez nos seus personagens paranoicos, para os quais a realidade se mostra inapreensível.

Essa estratégia pode parecer, à primeira vista, semelhante à de livros como $\mathrm{O}$ arco-íris da gravidade ou $\mathrm{O}$ leilão do lote 49, ambos de Thomas Pynchon. Nas palavras do crítico David Cowart:

Paranoia is, in fact, the conviction that mighty conspiracies exist, that all things are connected "in spheres of joyful or threatening about the central pulse of [one]self" $(L 49,129)$. Pynchon's protagonists come to believe in this infinite reticulation of conspiracy because it is preferable to the possibility that "nothing is connected to anything" (GR 434). Pynchon's readers, by the same token, encounter fictive structures that formally imitate the paranoid premise: all is connected in great, seamless web of interdependent detail. (COWART, 2011, pp. 5-6)

E, no entanto, a maneira como Bolaño articula a paranoia é diferente da de Pynchon e de outros escritores ditos maximalistas (uma definição que coloca o autor chileno no mesmo grupo de vários norteamericanos que também trabalham com a questão da paranoia). Para compreender essa diferenciação, é necessário, antes de mais nada, definir o que se quer dizer com paranoia, e então adentrar o texto em si.

A maneira como a paranoia se manifesta foi definida de forma concisa por Vladimir Safatle da seguinte maneira:

Tudo o que é desconhecido deve ser remetido a algo conhecido e referido ao doente. Isso leva o paranoico à necessidade compulsiva do desmacaramento. Ele quer que haja algo por trás dos fenômenos ordinários e só se acalma quando uma relação causal é encontrada. (SAFATLE, 2011, p. 223)

Essa definição encaixa-se perfeitamente com o protagonista de VALIS. Para Safatle, a partir de Krafft Ebbing, e comentando o supracitado Thomas Pynchon, a paranoia é tão recorrente na literatura pela sua busca por um ordenamento: 
contra a experiência da fragilidade dos mecanismos de produção e estabilização do sentido, a própria literatura começaria a mimetizar o procedimento paranoico de reconstrução da unidade narrativa através de interpretações delirantes, marcadas pelas temáticas da perseguição, do complô, da grandeza e da erotomania. (SAFATLE, 2011, p. 226)

A "Parte dos Críticos", assim como VALIS, é exemplar nesse sentido. Nessa primeira seção de 2666 , o problema dos crimes ainda não surgiu, é apenas um sussurro que escapa entre uma conversa e outra. $\mathrm{O}$ mistério, portanto, ainda é a busca por Archimboldi, e toda paranoia se constrói a partir de um mistério. Incapazes de acessar a realidade total, ou seja, incapazes de realizar um exercício de totalização, de abarcar o mundo, os personagens de Bolaño preenchem o vazio construindo uma ordem secreta entre os elementos.

O primeiro diálogo de 2666 aparece após quase vinte páginas de prosa corrida. É no meio de uma anedota sobre uma possível aparição de Archimboldi. Uma cena curiosa acontece com personagens irrelevantes em um pequeno povoado. Uma mulher conta uma história e faz uma pergunta que "no se dirigía a ninguno del pueblo" (BOLAÑO, 2004a, p. 39). A pergunta é a seguinte: "-¿Alguien es capaz de resolver el enigma?" (BOLAÑO, 2004a, p. 39).

Ou seja, o primeiro diálogo do livro enseja uma chave de leitura, uma pergunta jogada no vazio que constrói um mistério. $\mathrm{O}$ enigma em questão é irrelevante, ou falsamente relevante - um red herring, para usar termos de narratologia de cinema -, ao contrário do grande enigma do livro, isto é, os crimes, e a frase atua como uma provocação que reaparece como um eco espectral depois.

Analisada em contexto, essa cena parece desconexa, se não desconectada do romance. Os indícios de paranoia, em Bolaño, aparecem pontual e inesperadamente. Uma cena ordinária pode se tornar um enigma muito facilmente, e a "Parte dos Críticos" está repleta delas, desde essa cena no povoado até o mistério de por que o artista fictício Edwin Johns teria arrancado a sua mão.

Como disse antes, na "Parte dos Críticos", o mistério ainda não são os crimes, mas Archimboldi. É interessante observar, portanto, que nada sabemos sobre a obra de Archimboldi, exceto o título de alguns de seus romances e descrições vagas sobre seu estilo, suas influências etc. Acessamos Archimboldi sempre através do olhar dos críticos. Na página 
99, os críticos vão a um congresso intitulado "La obra de Benno von Archimboldi como espejo del siglo XX" (BOLAÑO, 2004a, p. 99). Mas em que sentido ela seria um espelho do século? A primeira coisa que pensamos é que se trata de mais uma paródia do mundo acadêmico, com seus títulos pomposos e ambiciosos de leituras de obras de ficção.

Porém, para além da ironia, esse artifício de apontar uma coisa pequena como ícone ou símbolo de algo muito maior, é recurso corrente em Bolaño. Ou seja, é um artifício metonímico, de sinédoque. Há um exemplo que me parece precioso para refletir sobre tal estratégia. Num "conto" (entre aspas, pois a definição não é nada clara) intitulado "El hijo del coronel”, coletado no volume póstumo El secreto del mal (2007), o escritor chileno descreve, em detalhes absurdos, toda a trama de um filme de zumbis assistido de madrugada. A descrição é linear e quase monótona, na sua busca por narrar cena a cena do filme. $O$ texto foi reunido num livro de contos, mas pesquisadores logo descobriram que o tal filme de zumbis existe: trata-se de A volta dos mortos vivos 3, dirigido por Brian Yuzna, bastante conhecido pelas suas adaptações de H. P. Lovecraft. O filme em questão, no entanto, nada tem de especial. Entre os filmes de zumbi, está longe do panteão criado por diretores como Romero e Fulci. O roteiro é estrambótico e estúpido. Todavia, antes de começar o suposto “conto", o narrador - o próprio Bolaño, se formos pensar que talvez o texto não seja de ficção - diz o seguinte:

No os lo vais a creer, pero ayer por la noche, a eso de las cuatro de la madrugada, vi en la tele una película que era mi biografía o mi autobiografía o un resumen de mis días en el puto planeta Tierra. Me cago en la hóstia santa, el susto que me dio casi hizo que me cayera del sillón. (BOLAÑO, 2007, p. 31)

Por que Bolaño, ou seu narrador ficcional, diria que aquele filme de zumbis é sua autobiografia? O leitor devora o "conto" na busca por uma explicação, mas não há resposta alguma. Nem mesmo estudando a biografia de Bolaño parece possível encontrar pontos de contato, metáforas, nada. O próprio narrador diz que é um filme ruim, repleto de lugares comuns, personagens caricaturais, embora

cada fotograma respiraba un aire de revolución, digamos un aire en el que se intuía una revolución, no la revolución completa, para que me entendáis, sino un trozo más bien 
minúsculo, como si vierais, por ejemplo, Parque Jurásico y no apareciera ningún dinosaurio por ninguna parte, vaya, como si en Parque Jurásico nadie mencionara ni una sola vez al jodido reptil, pero la presencia de éstos fuera omnipresente e insoportable. (BOLAÑO, 2007c, p. 32)

Esta é a estratégia: tomar algo minúsculo - no caso, um filme de zumbis ordinário e menor, até mesmo dentro do cânone de filmes de terror com o qual Bolaño o compara - e torná-lo símbolo de algo muito maior - no caso, a vida dele. ${ }^{196}$

Além disso, o leitor de Bolaño pode associar essa definição da obra de Archimboldi como "reflexo do século XX" com questões do nazifascismo - não seria La literatura nazi en América uma espécie de espelho (que não só reflete a imagem, mas a inverte) do cânone do século $\mathrm{XX}$ ?

No caso de 2666, sabemos, graças a esse título, que a obra de Archimboldi pode ser vista como o espelho de um século. Mas de que maneira isso ocorre, por que ela representaria algo maior? Não sabemos, nunca saberemos. Este é um convite para adentrar a lógica paranoica.

A obra de Archimboldi, misteriosa desde sempre, após o incidente com o taxista e o rompimento do triângulo amoroso, torna-se ainda mais elusiva:

la obra de Archimboldi, es decir sus novelas y cuentos, era algo, una masa verbal informe y misteriosa, completamente ajena a él, algo que aparecía y desaparecía de forma por demás caprichosa, literalmente un pretexto, una puerta falsa, el alias de un asesino, una bañera de hotel llena de líquido amniótico en donde él, Jean-Claude Pelletier, terminaria suicidándose. (BOLAÑO, 2004a, p. 113)

Ou seja, a obra de Archimboldi e a figura do escritor, um objetivo em cuja direção os críticos caminhavam, se mostra impossível de fixar. Problemas pessoais afastam os críticos da literatura; aquilo que eles

\footnotetext{
${ }^{196}$ No prólogo a Los sinsabores del verdadero policía (2011), menciona-se que Bolaño descreveu o projeto inacabado como "MI NOVELA" (p. 7) em 1995. Há muito pouco material propriamente autobiográfico no romance em questão.
} 
buscavam compreender e decifrar vira "una puerta falsa", ou seja, uma pista falsa (ou um red herring), e é num desses momentos em que Bolaño antecipa e anuncia temas, "el alias de un asesino". Não há dúvidas de que esta é uma chave de leitura inserida dentro do próprio texto, assim como a cena em que o farmacêutico diz preferir exercícios curtos de estilo a grandes obras cheias de excesso. É como se o narrador já declarasse, desde então, que a busca por Archimboldi - dos personagens e do leitor - será infrutífera, uma pista falsa para decifrar o mistério, o verdadeiro mistério.

Porém, qual é a salvação para os críticos obcecados? Não há salvação, apenas paranoia. Tudo se torna um símbolo possível. Quando Morini e os dois críticos do sexo masculino visitam Edwin Johns no hospício, percebem que uma enfermeira lê uma antologia de literatura alemã do século XX. $\mathrm{O}$ artista Edwin Johns, até este ponto do livro, não tinha a menor relação com Archimboldi, mas essa coincidência perturba a ordem vigente e sugere a existência de uma ordem secreta, paranoica:

Espinoza notó entonces que el libro al que la enfermera no le quitaba ojo era una antología de literatura alemana del siglo XX. Con el codo, avisó a Pelletier, y éste le preguntó a la enfermera, más por romper el hielo que por curiosidad, si estaba Benno von Archimboldi entre los antologados.

En ese momento todos escucharon el canto o la llamada de un cuervo. La enfermera respondió afirmativamente.

Johns se puso a bizquear y luego cerró los ojos y se pasó la mano ortopédica por la cara.

- El libro es mío - dijo -, yo se lo he prestado.

- Es increíble - dijo Morini -, qué casualidad.

- Pero naturalmente yo no lo he leído, no sé alemán.

Espinoza le preguntó por qué motivo, entonces, lo había comprado.

- Por la portada - dijo Johns -. Trae un dibujo de Hans Wette, un buen pintor. Por lo demás - dijo Johns -, no se trata de creer o no creer en las casualidades. El mundo entero es una casualidad. Tuve un amigo que me decía que me equivocaba al pensar de esta manera. Mi amigo decía que para alguien que viaja en un tren el mundo no es una casualidad, aunque el tren esté atravesando territorios desconocidos para el viajero, territorios que el viajero no volverá a ver nunca más en su vida. 
Tampoco es una casualidad para el que se levanta a las seis de la mañana muerto de sueño para ir al trabajo. Para el que no tiene más remedio que levantarse y añadir más dolor al dolor que ya tiene acumulado. El dolor se acumula, decía mi amigo, eso es un hecho, y cuanto mayor es el dolor menor es la casualidad.

- ¿Como si la casualidad fuera un lujo? - preguntó Morini. En ese momento, Espinoza, que había seguido el monólogo de Johns, vio a Pelletier junto a la enfermera, con el codo apoyado en el reborde de la ventana mientras con la otra mano, en un gesto cortés, ayudaba a ésta a buscar la página donde estaba el cuento de Archimboldi. [...]

- La casualidad no es un lujo, es la otra cara del destino y también algo más - dijo Johns.

- ¿Qué más? - dijo Morini.

- Algo que se le escapaba a mi amigo por una razón muy sencilla y comprensible. Mi amigo (tal vez sea una presunción de mi parte llamarlo aún así) creía en la humanidad, por lo tanto creía en el orden, en el orden de la pintura y en el orden de las palabras, que no con otra cosa se hace la pintura. Creía en la redención. En el fondo hasta es posible que creyera en el progreso. La casualidad, por el contrario, es la libertad total a la que estamos abocados por nuestra propia naturaleza. La casualidad no obedece leyes y si las obedece nosotros las desconocemos.

La casualidad, si me permite el símil, es como Dios que se manifiesta cada segundo en nuestro planeta. Un Dios incomprensible con gestos incomprensibles dirigidos a sus criaturas incomprensibles. En ese huracán, en esa implosión ósea, se realiza la comunión. La comunión de la casualidad con sus rastros y la comunión de sus rastros con nosotros. (BOLAÑO, 2004a, pp. 112-13)

O monólogo quase incoerente de Johns traz ao primeiro plano a discussão da coincidência. Pouco pode se deduzir desse diálogo, exceto, talvez, que não haja uma solução fácil para decidir o que é coincidência e o que é proposital na concatenação de símbolos em busca por formar uma ordem. A ideia central, porém, é a seguinte: a coincidência é libertadora, pois não exige que encontremos sentido. Mais uma vez, 
Bolaño nos oferece uma chave de leitura e uma antecipação: o quanto há de incompreensível nos crimes de Santa Teresa?

Para cada artifício de antecipação, porém, Bolaño usa um de adiamento. Quando o artista Edwin Johns finalmente decide revelar por que se mutilou, ele sussurra a resposta no ouvido de Morini (BOLAÑO, 2004a, p. 125). O narrador não conta o que foi dito; é como se o leitor fosse um dos outros críticos, que não consegue escutar o sussurro. Tratase de uma técnica de postergação narrativa; a informação voltará, enfim revelada, quando for proveitoso para o enredo.

Logo depois de ouvir o segredo, Morini desaparece misteriosamente, deixando Pelletier e Espinoza preocupados. Ao ligar para a universidade em busca de Morini, Espinoza escuta o estudante com quem fala repetir o nome de Morini, como se tentasse se lembrar. Porém, a esta altura, os personagens já estão mergulhados na lógica paranoica, e esse breve momento de hesitação dispara uma torrente de pensamentos confusos em Espinoza:

Y luego Espinoza oyó que alguien, el mismo estudiante, susurraba Morini... Morini... Morini, con una voz que no parecía la suya sino más bien la voz de un mago, o más concretamente, la voz de una maga, una adivina de la época del Imperio Romano, una voz que llegaba como el goteo de una fuente de basalto pero que no tardaba en crecer y desbordarse con un ruido ensordecedor, el ruido de miles de voces, el estruendo de un gran río salido de cauce que contiene, cifrado, el destino de todas las voces. (BOLAÑO, 2004a, p. 127)

Duas coisas devem ser observadas aqui: a primeira é que parece haver uma referência muito direta à obra de Philip K. Dick: "una adivina de la época del Imperio Romano”; em VALIS, o protagonista parece acreditar que a realidade subjacente ao nosso mundo é que ainda vivemos na época do Império Romano. O segundo detalhe a se observar: mais uma vez, Bolaño repete o artifício sinedótico de que algo pequeno representa outra coisa muito maior, no caso, um ruído que contém "cifrado" (atenção para a palavra usada) o destino de todas as vozes. $\mathrm{O}$ mistério permanece, pois é indecifrável. $\mathrm{O}$ mistério permanece, pois é uma totalidade, e a totalidade não é mais abarcável - um sintoma expresso de diferentes formas em boa parte da literatura contemporânea ou pós-modernista. 
Quando enfim aterrissam no México, o clima de paranoia é sobrepujante. Em uma cena, enquanto esperam Amalfitano no hotel, tudo parece surreal e incompreensível. E o pior, ameaçador:

Estos tipos están medio locos, dijeron Espinoza y Pelletier. Norton, por el contrario, pensó que algo raro estaba pasando, en la avenida, en la terraza, en las habitaciones del hotel, incluso en el DF con esos taxistas y porteros irreales, o al menos sin un asidero lógico por donde agarrarlos, e incluso algo raro, que escapaba a su comprensión, estaba pasando en Europa, en el aeropuerto de París en donde se habían reunido los tres, y tal vez antes, con Morini y su negativa a acompañarlos, con ese joven un tanto repulsivo que conocieron en Toulouse, con Dieter Hellfeld y sus repentinas noticias sobre Archimboldi. (BOLAÑO, 2004a, pp. 151-52)

Os sonhos dos críticos no México são descritos de forma extensa. Em um deles, Norton enxerga uma mulher no seu quarto, pega um caderninho e toma notas muito rapidamente de tudo o que acontecia, "como si en ello estuviera cifrado su destino". (BOLAÑO, 2004a, p. 155; grifo meu)

A América Latina tem um efeito desagregador nos críticos europeus. A narrativa, a partir desse ponto, abandona o realismo duro que seguia nas primeiras páginas. $\mathrm{O}$ onírico se mistura ao real através de uma lógica de incertezas.

Depois de uns dias no México, quando lá decidem permanecer mais um tempo e passam a viver como se morassem em Santa Teresa, os críticos veem a sua realidade desabar e uma nova realidade - uma nova ordem, uma nova lógica subjacente - emergir:

A partir de ese momento la realidad, para Pelletier y Espinoza, pareció rajarse como una escenografía de papel, y al caer dejó ver lo que había detrás: un paisaje humeante, como si alguien, tal vez un ángel, estuviera haciendo cientos de barbacoas para una multitud de seres invisibles. (BOLAÑO, 2004a, p. 179)

A paisagem que se entrevê é, na falta de outras palavras, apocalíptica. 


\section{A loucura de Amalfitano}

Na segunda parte do romance, focada no professor Amalfitano, a questão da paranoia ressurge. $O$ elemento catalisador desta no personagem é um livro de poesia que, ao contrário das obras de Archimboldi, de fato existe, ainda que tenha se tornado raríssimo: Testamento geométrico, de Rafael Dieste.

Obcecado com a aparição misteriosa do volume em sua casa, inexplicável e impossível de rastrear, Amalfitano é contagiado pelo uso de figuras geométricas do livro e passa também a usar triângulos e retângulos em suas aulas. Nessas figuras, elenca nomes de filósofos, sem formar nenhuma conexão lógica entre eles, e depois até mesmo a ordem de aterse a filósofos se perde: passa a colocar nomes históricos, como o ideólogo do aparato stalinista e o crítico literário Harold Bloom.

O leitor de Bolaño, acostumado com a avalanche de nomes que costumam ser citados em seus romances, procura encontrar uma lógica, uma explicação para os desenhos de Amalfitano. Há temas de Bolaño sendo indiretamente citados e conectados: a ditadura, no caso, o stalinismo, e o cânone literário de Bloom. Uma conexão entre cânone e ditadura, literatura e violência? Sim, sem dúvida: mas como se dá essa ligação? Amalfitano não compreende, e o leitor tampouco.

É como se Bolaño retornasse ao tema mais presente em sua obra - a dualidade ética/estética, violência/arte - pelo viés da loucura do intelectual, o intelectual que não consegue explicar como funciona essa ordem tão complexa. O que temos é uma cascata de citações, um universo intertextual em expansão, ${ }^{197}$ que não volta a se fechar, isto é, que não se reduz ou se adequa a uma lógica, portanto inabarcável.

Como se não fosse o bastante, Amalfitano pendura o livro de Dieste em um varal, numa relação intertextual com a obra artística de Duchamp, algo que ele mesmo se dá conta. O narrador interrompe a ação para citar a biografia de Duchamp escrita por Calvin Tomkins, em um momento de ampla autoconsciência narrativa: primeiro, afirma que Duchamp não apenas jogou xadrez em Buenos Aires, como também realizou esta obra, e cita textualmente a biografia como prova. Linhas depois, porém, o narrador autoconsciente afirma: "Me retracto, en realidad lo que Duchamp hizo en Buenos Aires fue jugar al ajedrez." (BOLAÑO, 2004a, p. 246).

${ }^{197}$ Parafraseando Chris Andrews (2014). 
Com isso, Amalfitano torna a sua loucura um espaço de citação artística. Em outras palavras, ele performatiza sua loucura. Para a crítica Graciela Ravetti,

Embora impotentes para evitar a dor, tais irrupções artísticas funcionam como instalações conceituais no meio da catástrofe, como sinalizadores programáticos da criação possivel de sentido e acabam revelando a crise geral de significação que acomete a América Latina no século XX. (RAVETTI, 2016, p. 66)

E ainda:

O que está em jogo é a angústia produzida pela ordem geral, estilhaçada em fragmentos desapontadores, que incapacitam Amalfitano a seguir um raciocínio coerente e, em contraste pacificador, o repentino abrigo emocional e intelectual que encontra na súbita saída salvadora pela arte, que não exige a ficção de um argumento esclarecedor nem o preciosismo de uma ekphrasis erudita. (RAVETTI, 2016, pp. 72-73)

A fragmentação sinaliza a tentativa de criar sentido em meio à crise de significação. Enquanto isso, os crimes de Santa Teresa ocorrem; Amalfitano assiste à TV e os ignora (BOLAÑO, 2004a, p. 248). A cidade lhe parece terrivel, ainda que seu horror seja representado pelo gosto da água, que ele jura ser capaz de escurecer os dentes com uma fina película de sujeira subterrânea (p. 261). Incapaz de lidar com essa nova realidade, longe de sua Barcelona, Amalfitano vê mais lógica na arte do que na cidade de Santa Teresa, numa busca de sentido:

Cuando llegaron a casa ya no había luz pero la sombra del libro de Dieste que colgaba del tendedero era más clara, más fija, más razonable, pensó Amalfitano, que todo lo que había visto en el extrarradio de Santa Teresa y en la misma ciudad, imágenes sin asidero, imágenes que contenían en sí toda la orfandad del mundo, fragmentos, fragmentos. (BOLAÑO, 2004a, p. 265)

A realidade é fragmentada, a busca de sentido se dá através da arte, mas como proceder quando há uma dispersão ininterrupta intertextual? 
No parágrafo seguinte (p. 265), Amalfitano está aguardando a voz misteriosa que conversa com ele, alucinação auditiva que parece tirada de uma catalogação de sintomas da esquizofrenia. Em sua frente, um papel em branco. Quando torna a olhar, vê que preencheu em três fileiras nomes de filósofos, escritores, intelectuais, nomes díspares como Marx, Sade, Lacan, Freud, Locke e Wittgenstein. Ele busca uma lógica, lê fora de ordem, ao contrário, cruzando fileiras, em busca de um sentido, uma revelação. A arte também não é mais ordenadora.

No meio desse desvario, Amalfitano lembra-se de "Raimundo Lulio y su máquina prodigiosa. Prodigiosa por inútil.” (BOLAÑO, 2004a, p. 265). Lulio, um mártir franciscano do século XIII, é considerado um dos fundadores da lógica ao tentar montar um sistema combinatório de termos do qual derivar-se-ia a doutrina cristã. Ele é citado por inúmeros escritores comumente associados ao pós-modernismo, como Paul Auster e William Gaddis. Em 2666, a menção paródica a Lulio sinaliza uma falência dos sistemas de informação e lógica por parte de Amalfitano. Como Lulio, Amalfitano procura construir uma sistematização da qual seria possível derivar uma resposta; porém,

Durante un rato, Amalfitano leyó y releyó los nombres, en horizontal y vertical, desde el centro hacia los lados, desde abajo hacia arriba, saltados y al azar, y luego se rió y pensó que todo aquello era un truismo, es decir una proposición demasiado evidente y por lo tanto inútil de ser formulada. (BOLAÑO, 2004a, pp. 265-66)

Não se trata exatamente do fato de que Amalfitano não encontre nada; o que ele encontra parece óbvio demais. Citando de forma descontextualizada a crítica Graciela Ravetti (2016), "o segredo do mundo é óbvio". Logo após esta frustrante revelação, Amalfitano bebe água e tem novamente a ilusão de estar apodrecendo; ao olhar pela janela vê a sombra do livro pendurado, que lhe parece uma "sombra de ataúd" (BOLAÑO, 2004a, p. 266). O livro de geometria está equiparado, nesse jogo associativo, à morte. Talvez esse tenha sido o truísmo tão evidente que nem precisava ser formulado que Amalfitano encontrou.

A loucura de Amalfitano persiste, mas logo muda de foco e tema. Amalfitano segue sem entender o que é a voz que conversa com ele, mas ao invés de buscar respostas na confluência das ciências exatas com a arte (poesia e geometria, ready-made e acaso), passa a refletir sobre telepatia indígena. A mudança de objeto é brusca. Após sair para beber com o filho 
450 | Antônio Carlos Silveira Xerxenesky

do reitor, um sujeito reacionário e um tanto sinistro, ${ }^{198}$ que anda armado, em uma cena repleta de tensão latente, Amalfitano chega em casa e se lembra de um livro que leu sobre os poderes dos araucanos. Vamos ao texto para perceber quão repentina é a mudança de foco do livro:

Cuando llegó a su casa Amalfitano olvidó de inmediato al joven Guerra y pensó que tal vez no estaba tan loco como creía ni tampoco la voz era un alma en pena. Pensó en la telepatía. Pensó en los mapuches o araucanos telépatas. Recordó un libro muy delgado, que no llegaba a las cien páginas, de un tal Lonko Kilapán, publicado en Santiago de Chile en el año de 1978, que un viejo amigo, humorista de ley, le había enviado cuando él vivía en Europa. (BOLAÑO, 2004a, p. 267)

A partir desse momento, Duchamp e Dieste perdem força, e o livro de Kilapán torna-se o centro. A loucura de Amalfitano passa a se tornar, como a de Lola, uma loucura episódica. Nas páginas seguintes, lemos trechos do livro através de Amalfitano, e muitas vezes temos acesso a citações ipsis litteris, inclusive de notas de rodapé. Mais ao final, Amalfitano reflete, balançando a cabeça ao ritmo do livro pendurado no varal, poderia muito bem ser um pseudônimo de Pinochet, ou de qualquer neofascista (pp. 286-87). O eterno tema de Bolaño retorna - a ligação entre ética e estética - e é possível perceber ecos de La literatura nazi en América: Kilapán, que, ao contrário do cânone fictício de La literatura nazi, de fato existe, não apresenta, pelo menos não nos trechos que Amaliftano revela ao leitor, motivos para ser comparado com um fascista. A sua relação com um estilo neofascista é difusa, e provém apenas da interpretação inesperada e, logo a seguir, delirante de Amalfitano.

${ }^{198}$ Esse personagem pouco explorado no livro é bastante curioso: de um lado, parece um tipo perigoso e violento, prestes a explodir, que frequenta apenas os piores locais da cidade. Por outro, é um literato com um discurso que se assemelha ao do narrador de Estrella distante (2006): ele defende que a literatura está corrompida, e que só a poesia é um alimento saudável (BOLAÑO, 2004a, p. 289). A literatura, para o jovem Guerra, está repleta de enganadores, egoístas e traidores (BOLAÑO, 2004a, p. 268). 
O protagonista começa investigando o livro de Kilapán interessado nos fatores místicos-sobrenaturais ali descritos, em busca de uma compreensão melhor de sua loucura, da voz que escuta. Porém, logo seu interesse se desvia para o fato do livro ter sido publicado durante a ditadura militar chilena e todo o aparato acadêmico que validava o livro naquela época, tornando-o um livro "de respeito" (p. 285). A partir daí, associa Kilapán a Pinochet e, depois, num delírio associativo, a movimentos neofascistas e imagens desconexas, de vacas pastando no deserto do Atacama ao muro de Berlim (p. 287). Findo o desvario, retorna à questão da telepatia e descobre que a mãe de poderes telepáticos chama-se Isabel Riquelme, e que sua mãe tem o nome de Eugenia Riquelme (na verdade, algo muito mais longo, ironizando a relação: Filia María Eugenia Riquelme Graña). Ele se arrepia, pensando ter descoberto algo. A lógica paranoica está de volta.

Qual é o arco do personagem? O caminho de uma loucura a outra? Amalfitano começa louco e termina louco, mas a sua insanidade foi contaminada por questões políticas. A Parte de Amalfitano termina com um sonho no qual Boris Yeltsin dá uma aula bizarra sobre marxismo, oferecendo uma equação que adiciona uma camada mística ao materialismo marxista:

Te voy a explicar cuál es la tercera pata de la mesa humana. Yo te lo voy a explicar. Y luego déjame en paz. La vida es demanda y oferta, u oferta y demanda, todo se limita a eso, pero así no se puede vivir. Es necesaria una tercera pata para que la mesa no se desplome en los basurales de la historia, que a su vez se está desplomando permanentemente en los basurales del vacío. Así que toma nota. Ésta es la ecuación: oferta + demanda + magia. ¿Y qué es magia? Magia es épica y también es sexo y bruma dionisiaca y juego. (BOLAÑO, 2004a, p. 291)

A impressão que temos é de síntese: Amalfitano, no seu inconsciente, sonha com a fusão entre o materialismo (a geometria de Dieste, a lógica de Lulio, o materialismo de Marx) e o místico (a telepatia dos araucanos, a magia de que fala Yeltsin) ${ }^{199}$. Magia como épica, como

199 Também pode-se pensar em ecos de Borges, que no ensaio "A arte narrativa y a magia”, contrasta duas formas de escrita, uma mimética e verossímil, e outra "mágica", na qual as relações causais são outras, pois 
sexo e bruma dionisíaca: é isso que impedirá a história de cair no lixão do vazio. Arte, em resumo, ou: um modo específico de ver a arte. Talvez uma arte do excesso.

\section{$3 \mathrm{~A}$ arte do excesso}

É uma marca da prosa de Bolaño um tipo de afirmação categórica que busca definir o que será narrado logo depois. Relembremos a abertura da novela Amuleto, citada alhures: "Esta será uma história de terror. Será uma história policial, uma narrativa de série negra e de terror. Mas não parecerá. Não parecerá porque sou eu que conto." (BOLAÑO, 2008a, p. 9).

O recurso gera um suspense - de onde virá o horror? E assim começamos a ler uma história sobre poetas latino-americanos sempre aguardando a manifestação do terror anunciado.

Em um dos ensaios compilados em Toda a orfandade do mundo (2016), Marcos Natali recolhe três exemplos dessa estratégia narrativa: a abertura de Amuleto, a abertura de "El ojo Silva", que promete contar uma história de violência inescapável, e a epígrafe de 2666, já discutida aqui. Para Natali, através desse recurso, Bolaño constrói uma espécie de profecia narrativa, e a leitura do texto em si envolve, então,

confrontar, por um lado, a expectativa gerada pela proclamação feita no início da narrativa, o sentido da parábola sombria proposto já em sua abertura, e, por outro lado, o que sobra - o que sobra na história e também da história, pois o que sobrevive e chega até nós é também uma narrativa. Trata-se, assim, do exercício de examinar a equivalência entre princípio organizador e a narrativa, isto é, do trabalho de discernir se existe na narrativa algo que exceda e desestabilize o princípio geral. Assim, como em todo discurso profético, tudo no conto se jogará na relação entre a profecia e o seu resto. (NATALI, 2016, p. 20)

Esta análise é preciosa: as profecias de Bolaño incitam o confronto entre o previsto e o que escapa do previsto, ou não se adequa a ele. Em 2666, acredito que a situação seja ainda mais complexa, pois embora a

"Un orden muy diverso los rige, lúcido y ancestral. La primitiva claridad de la magía” (BORGES, 2012, p. 140). 
epígrafe - citando via Baudelaire um oásis de horror em meio a um deserto de tédio - funcione como profecia-mor, o autor chileno espalhou por todo o livro pequenos trechos que servem, se não como profecia stricto sensu, como chaves de leitura, são tentativas de definir "princípios gerais", de elaborar totalizações do impossível de totalizar - "fragmentos, fragmentos", como a mente fraturada de Amalfitano enxerga.

Se a epígrafe de 2666 oferece, então, uma espécie de topologia, ou talvez uma cartografia da estrutura do romance, a conversa que Amalfitano tem com o farmacêutico sobre romances excessivos e gigantescos vs. exercícios perfeitos de estilo proporciona uma defesa da ética do romance monstruoso. A grande obra é arriscada. ${ }^{200}$ Amalfitano fastidia-se com as "sessões de treino de esgrima" dos grandes autores, preferindo os "combates de verdad, en donde los grandes maestros luchan contra aquello, ese aquello que nos atemoriza a todos, ese aquello que acoquina y encacha, y hay sangre y heridas mortales y fetidez". (BOLAÑO, 2004a, p. 290)

Pode-se ler esse trecho como uma defesa da proposta não apenas formal como ética do romance em questão. $\mathrm{O}$ autor reconhece que é através do excesso que se encontra o risco, "a escrita como tauromaquia", onde há sangre e podridão (os crimes como centro), mas, enfim, essa é a forma literária que vale a pena cultivar. No entanto, para construir uma obra de excesso, será necessário trabalhar com fragmentos que não necessariamente se encaixarão numa ordem lógica, e na ausência dessa grande ordem, a paranoia surge como método de interpretação de mundo. Ela não está apenas nos personagens, mas também difusa em toda a narrativa.

Bolaño joga com a patologia da imaginação paranoide através de artifícios de suscitação de mistérios e adiamento ou frustração de desenlaces (negando ao paranoico a satisfação de ver o mundo encaixar-se à sua ordem imaginada); de uma proliferação radical de significantes e de excesso narrativo que incita a busca por conexões mesmo quando não há (a listagem forenses de como os corpos foram encontrados, por exemplo); e, por fim, de uma abertura ao mencionar temas amplos e estabelecer

200 Roberto Bolaño disse, em entrevista a Carmen Boullosa (2006), ao tratar do romance policial e da ficção científica, isto é, a literatura de gênero dita "menor", que esta é um luxo inalcançável no cenário "monótono ou apocalíptico" da América Latina, onde escritores sempre imitam ou rejeitam as grandes obras europeias. 
454 | Antônio Carlos Silveira Xerxenesky

diálogos intertextuais parcialmente explorados que acabam sendo red herrings em alguns casos.

A paranoia, então, mais do que sintoma ou reflexo, é um modus operandi literário. Roberto Bolaño vem sendo apontado como um farol para a nova geração de escritores; a arte do excesso que não esconde seus resíduos, dejetos e partes mal encaixadas em 2666 pode muito bem representar um caminho, uma linha-mestre, na literatura contemporânea.

\section{REFERÊNCIAS}

ANDREWS, C. Roberto Bolaño's Fiction: An Expanding Universe. Nova Iorque: Columbia University Press, 2014.

BOLAÑO, R. 2666. Barcelona: Anagrama, 2004a.

BOLAÑO, R. Amuleto. São Paulo: Companhia das Letras, 2008a.

BOLAÑO, R. El espiritu de la ciencia ficción. Cidade do México: Anagrama, 2016.

BOLAÑO, R. El secreto del mal. Barcelona: Anagrama, 2007.

BOLAÑO, R. Entre paréntesis: ensayos, artículos y discursos (1998-2003). Barcelona: Anagrama, 2004b.

BOLAÑO, R. La literatura nazi en América. Barcelona: Anagrama, 2010.

BOLAÑO, R. Los sinsabores del verdadero policía. Barcelona: Anagrama, 2011.

BOLAÑO, R. Putas assassinas. São Paulo: Companhia das Letras, 2008b.

BORGES, J. L. Discusión. Buenos Aires: Debolsillo, 2012. COWART, D. Thomas Pynchon and the Dark Passages of History. Georgia: University of Georgia Press, 2012

DICK, P. K. VALIS and Later Novels. Washington: Library of America, 2009.

ERCOLINO, S. The Maximalist Novel: From Thomas Pynchon's Gravity's Rainbow to Roberto Bolaño's 2666. Londres: Bloomsbury Academic, 2014.

MARISTAIN, M. Bolaño: A Biography in Conversations. New York: Melville House, 2014.

NATALI, M. P. Da violência, da verdadeira violência. In: PEREIRA, A. M; RIBEIRO, G. S. Toda a orfandade do mundo. Belo Horizonte: Relicário, 2016.

SAFATLE, V. Paranoia como catástrofe social: sobre o problema da gênese de categorias clínicas. Trans/Form/Ação, v. 34, n. 2, pp. 215-36, 2011. 
Mensagens cifradas: paranoia em 2666 de Roberto Bolaño | 455

RAVETTI, G. Roberto Bolaño: o segredo do mundo é óbvio. In: PEREIRA, A. M; RIBEIRO, G. S. Toda a orfandade do mundo. Belo Horizonte: Relicário, 2016.

Recebido em: 20/08/2019

Aceito em: 25/09/2019 